\title{
Reformation og deformation ${ }^{1}$
}

\author{
Professor, dr.theol. Peter Widmann
}

\begin{abstract}
The aim of the Reformation movement was to overcome the destructive developments of the Western Catholic Church, not to establish a different Church or independent communities. The Reformers, however, were from the beginning confronted with the charge of deforming rather than reforming the Church, and this led to the split of Western Christianity and the emergence of Protestantism. The development of Protestantism was driven by different attempts to renew Christianity but the outcome thereof was often criticised as a destruction of the entire Christian tradition. The Protestant theology of the $20^{\text {th }}$ century in the wake of Karl Barth regarded itself as opposed to two deformations, one represented by Roman Catholicism, another by "neo-protestantism" respectively. This makes it clear that the threat of Christianity's deformation cannot be overcome by turning back to something original but demands a quest for new Christian realizations.
\end{abstract}

Key words: Reformation - Deformation - Protestantism - Neo-Protestantism.

Spørgsmålet om religionen har en fremtid besvares i dag oftest bekræftende, også af dem der slet ikke kan lide denne udsigt. Ganske vist har man i det ny århundrede set en opblussen af radikal religionskritik forbundet med en forventning om, at religionen snart vil være lige så fortidig som stenøkser eller orakler. Men mere udbredt end denne tiltro til, at videnskab og politik vil kunne tage religionens plads, er sikkert en - måske skeptisk, måske skadefro - benægtelse af den moderne vestlige kulturs kraft til at overleve. Mere eller mindre desperate røster om at afvikle Oplysningens og humanismens og frihedsrettighedernes idealer har højkonjunktur.

Set i dette perspektiv er det religionen i en fanatisk og før-moderne skikkelse, der har de bedste fremtidsudsigter; mens religionen $\mathrm{i}$ en mere moderat udgave, i pagt med frihedsrettighederne og i samklang med humaniteten og i vekselvirkning med den moderne videnskab, tilhører det døende vestlige samfund. Så forventningen om, at religi-

1. Indledningsforedrag ved forskerseminaret "Reformation og deformation: Protestantismen til debat", Aarhus Universitet d. 7. maj 2010. 
onen har en fremtid, gælder i manges øjne netop ikke for den religion, der er vores. Kristendommen og da især dens moderne udvikling efter reformationen, ikke mindst i skikkelse af den moderne protestantiske teologi, tilkendes ikke de store fremtidspotentialer. Og det er ikke blot udenforstående iagttagere, der anser protestantismens sag for tabt, men denne opgivelse begynder at inficere teologer og kirkefolk inden for de reformatoriske kirkesamfund. Også her i landet kan man spore tegn herpå. Ingen tvivl om, at det er desperation, og den skal man altid uden diskussion holde sig fra. Men lige så sikkert er det, at heller ikke en desperat påståelighed nytter noget. Man skal spørge nøgternt om fremtidsdueligheden af en af reformationen inspireret teologi.

\section{Reformationen anklages}

En vurdering af reformationens potentialer kræver allerførst et klart begreb om reformationens ret og raison d'être: Kan man opretholde, eller i det mindste gengive meningsfyldt, hvad der har været reformationens basale påstand, nemlig at den ikke er andet end en ny varetagelse af den oprindelige kristendom? Uroen i dette spørgsmål kommer fra de udviklinger og konsekvenser, som reformationen har udløst og medført. For selv om det skulle være muligt at udlægge reformatorernes, og da især Luthers teologi som værende i overensstemmelse med det grundlæggende i kristendommen, så har den efterfølgende historie, især i skikkelse af "neo-protestantiske" udviklinger, ofte ført meget langt derfra. Mange - og da ikke mindst de forskellige forsøg på at revitalisere den æote kristendom - har udtrykkeligt og virkningsfuldt beskyldt den moderne protestantisme for at være et frafald fra kristendommen. Det har ikke alene pietister og fundamentalister hævdet, men mange førende teologer, her i landet både Grundtvig og Kierkegaard. På vores egen plads her i Århus har Regin Prenter, i Protestantismen i vor tid (1957) talt om to slags protestantisme, dels den ægte, i reformationen rodfæstede, dels den til borgerlig ideologi degenererede moderne, mere eller mindre folkelige protestantisme.

Når det hævdes, at der i reformationens kølvand er indtrådt en deformation af kristendommen, fremprovokeres spørgsmålet, om reformationen kan frikendes fra at have udløst denne deformation, måske imod sin egen intention. Fra begyndelsen af har netop dette været den romersk-katolske kirkes anklage (interessant nok kom der fra reformationstidens radikale fløje såsom døbere og spiritualister næsten samtidigt lignende beskyldninger). Reformationen angribes for selv 
at være kristendommens deformation og derigennem alle moderne deformationers moder.

Anklagen for deformation retter sig - sådan har det i hvert fald været i det 16. århundrede, men på trods af økumeniske tilnærmelser er anklagen ikke trukket tilbage - navnlig mod tre forfaldsprocesser:

1. Læremæssige afvigelser: overdrivelser i syndslæren; tilsvarende yderligheder i nådelæren; udtynding af sakramentets mysterium; en deraf følgende underbestemmelse af det kirkelige embede.

2. Den kirkelige enheds opløsning på grund af subjektivitetens magtovertagelse.

3. De sakrale ordningers, institutioners og symbolers verdsliggørelse og i konsekvens heraf samfundets og alle fællesskabers opløsning samt sækulare magters overgreb på kirkens suverænitet.

Hvis man fremfører den slags anklager, vil man betragte de nyprotestantiske udviklinger, ikke blot den ortodokse læres og de hierarkiske ordningers udtynding og omtydning fra Oplysningens tid, men også de kristne konturers opløsning i forlængelse af modernitet og postmodernitet, for at være uundvigelige følger af reformationen.

\section{Reformation imod kristendommens deformation}

Den nævnte anklage får en særlig accent ved, at den eneste legitimation, som reformatorerne har kunnet opbyde imod det herskende kirkelige hierarki, lå i påstanden om de kirkelige tilstandes deformation og derfor reformationens nødvendighed. Kristendommens deformation blev vitterlig, hævdede reformatorerne, når man sammenlignede med det uforfalskede og oprindelige evangelium, som det taler til os gennem den hellige Skrift. Skriftens sandhed og autoritet var anerkendt af kirkeledelsen. Derfor mente reformationen at have ret til at spørge denne kirkeledelse, om den lod sig måle og dømme efter Skriftens målestok. Skriften taler tilstrækkelig klart, mente reformatorerne, til at fremholde et alternativ til den herskende kirke, et alternativ de havde ret til at iværksætte under påberåbelse af Kristus som troens genstand. Det var især flg. deformationer, reformationen mente at kunne diagnosticere i kirkens tilstand:

1. En læremæssig korruption: Skriftens evangeliske lære, som reformatorerne også fandt udtrykt i det kirkelige dogme, blev ganske 
vist ikke åbent tilsidesat; men evangeliet blev gjort kraftesløst ved, at man indførte tilføjelser af en ganske anden art, nemlig menneskelige opfattelser om menneskets evner og egne bidrag.

2. En usurpation af kirkens enhed: Under påberåbelse af kirkens udelelige integritet krævede den kirkelige myndighed ubetinget lydighed, også hvor troende var bundet i deres samvittighed af evangeliet; kirkens autoritet blev gjort gældende på tyrannisk vis, fordi den troende tilslutning til evangeliet blev truet med udelukkelse og forbandelse.

3. En verdsliggørelse af det gejstlige regimente: Varetagelsen af kirkens ledelse over mennesker og institutioner skete efter verdslige principper såsom magtpolitik, økonomiske interesser og selvopfundne menneskeligt kloge især filosofiske grundsætninger; de troendes liv styredes ikke af evangeliets frigørende ånd, den blev lænket og dæmpet af verdslige kræfter.

Disse deformationer betød alle sammen og hver for sig, at kirken havde opbygget sig selv som konkurrent til Kristus. Med den reformatoriske diagnose af den herskende kirke som deformeret hævdede reformatorerne at kunne hjælpe til, at liv og lære, kirke og samfund, fik lov at udfolde sig frit i lydighed mod Guds ord. Reformationens raison d'être var således en påstand om, at det var muligt og nødvendigt at lade Kristus være kirkens hoved, og at en tilbagevenden til Kristus kunne skabe betingelserne for en udfoldelse af det kristelige liv frigjort for de nævnte deformationer, og i overensstemmelse med det i Skriften bevidnede oprindeligt kristne ideal.

Fra begyndelsen af rejste der sig flg. spørgsmål, der blev gentaget og fornyet gennem århundrederne: Hvor langt strækker den reformatoriske kritik sig, og hvor langt skal man gå tilbage for at finde det oprindelige, der skal fornys?

1. Var kritikken rettet mod "middelalderen" (som man sagde senere) og de karakteristiske "kristne" formationer (såsom statskirkelighed, trostvang, trossymbolers brug som magtsymboler) i de europæiske stater, der blev arvtagere af Romerriget? Bestod opgaven i at opløse den sammenrodning af religion og politisk magt, der karakteriserede både det "gejstlige" og det "verdslige" herredømme? Gjaldt det om at udrense overtroiske, magiske, mytiske og pagane elementer fra kristendommens liv og lære for at frilægge evangeliets klarhed? Rettede kritikken sig mod den særlige kombination af tro (herunder Bibelens og dogmernes autoritet) og fornuft (her- 
under elementer af den antikke videnskabelighed), sådan som den herskede i skolastikken, for i stedet at skelne klart mellem det guddommelige ord, der skal siges til os, og fornuftens principper, som vi skal sige os selv? Var det reformatoriske anliggende en fornyelse af den kristne kærlighedsfordring, som den gælder alle troende, imod det falske overbud af fordringen gennem elitært selvvalgte asketiske og mystiske idealer? Drejede det sig om at hævde den kristne frihed og samvittighedens ret imod et tyrannisk formynderi i et sakralt retssystem?

2. Eller gik den reformatoriske kritik meget længere end til middelalderlige særudviklinger? Gjaldt det om at overvinde hele udformningen af den katolske kirke, som den kan ses fra det fjerde århundrede (eller måske endnu tidligere)? Lå der i påberåbelsen af Det Nye Testamente en distancering fra det kirkelige dogme med dets blanding af bibelske elementer og hellenistisk tankegang, der fremstod som en krydsning af de fattiges budskab med magtens dekreter? Ramte kritikken selve kirkens konstitution som sakramental frelsesanstalt for i stedet at sætte de troendes samfund? Sigtede reformationen mod en afskaffelse af den monarkisk-episkopale forfatning og det kirkelige embedes magtkrav, og derved mod den politiske magts forankring i en sakral retssfære? Det er vitterligt, at reformatorerne ikke åbent gik så langt. Med stor beslutsomhed fastholdt de det kirkelige dogme, sakramentets begreb, det kirkelige embedes autoritet og den konstantinske statkirke-struktur for at kunne styre de revolutionære energier hos spiritualister, entusiaster, kiliaster og døbere. At denne fastholdelse af bærende elementer i den middelalderlige katolske kirke var problematisk fremgår bl.a. af to omstændigheder: dels var det netop i denne forbindelse reformatorerne mente at skulle hidkalde statslige magtmidler og tvangsforanstaltninger, dels var deres argumentation for fastholdelsen ofte ikke på højde med deres centrale udlægning af evangeliet, men snarere præget af halvheder og dårlige kompromisser. Desuden finder man hos reformatorerne ikke blot den omtalte fastholdelse af træk fra den katolske kirkes historie, men også væsentlige ansatser til en kritik af den katolske kirkes formation i de første århundreder, ja endda i nytestamentlig tid. I forlængelse af denne kritik ligger nyprotestantiske udviklinger, både i dogmatik, kirkeforståelse og historisk udforskning af kirkens tekster og historie.

3. Eller var dynamikken i reformationens søgen efter urkristendommens rene forkyndelse endnu mere sprængfarlig? Gjaldt det om at 
finde et ubrudt liv, som ganske vist bevidnes i de nytestamentlige skrifter, men som tillige tildækkes og fejlrepræsenteres af de skrevne ord? Er de påstande, forestillinger, retssætninger, beretninger etc., som vi forefinder hos de bibelske især nytestamentlige forfattere ikke allerede forfaldsprodukter og stivnede rester efter en uhørt livsudfoldelse, som ikke længere er til stede i det foreliggende? Er det således allerede en deformation af evangeliet, når man identificerer det med et sæt foreliggende ytringer? Det er åbenbart, at reformatorerne ikke har fremsat den slags opfattelser, og når de har strejfet dem, har de med forfærdelse manet dem i jorden. Ikke desto mindre kan man spørge, om der ikke var en dynamik i den reformatoriske lidenskab efter at høre ordet, der gik i nævnte retning. Man kan tilføje, at f.eks. Luthers skelnen mellem det mundtlige og det skrevne ord og mellem skriftens ydre og indre klarhed kan føre til åbninger mod de anførte tanker. Da sådanne åbninger senere i de radikale udløbere af nyprotestantisk tankegang blev fremført utvetydigt, var det ikke uden inspiration fra en reformatorisk dynamik. Man kan ikke bare tilskrive den nyprotestantiske udvikling ganske andre kilder, f.eks. mystiske eller neoplatoniske. I denne forstand findes der en linje fra reformationen til teologier med en bevidst ændring af den kristne overlevering, ja endda til talsmændene for en afvisning af embede, dogme og fikseret lære. Og disse peger igen i retning af moderne religionskritik og af den i dag yderst populære kultur, der favoriserer det vilkårlige individuelle valg.

De tre nævnte udstrækninger af den reformatoriske kritik fører til en vigtig iagttagelse, nemlig at det ikke er muligt utvetydigt at sætte reformation mod deformation. De to størrelser ville kun kunne sondres utvetydigt, hvis kristendommen identificeredes med et sæt klart konturerede livs- og læreformer uden nogen deformation, der stod overfor vitterlige afvigelser og korruptioner. Men netop dette ville være en forenkling, og tilmed ganske uhistorisk (noget tilsvarende gælder da m.h.t. modsætningen mellem ortodoksi og hæresi i den ældste kristendom). Man kan i denne forbindelse nævne et tidligt eksempel på radikaliseret reformatorisk kritik, nemlig Gottfried Arnolds Unparteiische Kirchen-und Ketzer-Historie (1699-1700), hvor den uforfalskede kristendom bringes i nærheden af forkætrede afvigelser, mens de sejrrige ortodokse beskyldes for ukristen teori og praksis. Netop en søgen efter det ægte og sande medfører ofte en ødelæggelse af det vedtagne og vante (som traditionens talsmænd altid føler som deformation). Og hvis man for alvor vil overvinde herskende deformationer kan man næppe undgå at komme i naboskab af det 
hæretiske. Hvis ikke man har mod til at destruere hvad der har udviklet sig til legitim kirkelighed kan man ikke finde den oprindelige kristendoms nyhed.

I lyset af denne spænding skal også nyprotestantismens udvikling ses. Det er let at pege på teologiske nybrud, der søger at alterere det kristne. Eksempler: forsøgene på at reducere religion til moral som i dele af Oplysningen; den derved iværksatte eliminering af forløsningens nødvendighed; Kristus-skikkelsens omtolkning til eksempel på et humant ideal; omtolkningen af evangeliet fra korsets budskab til optimistisk manifest o.l. Men man må spørge, om der i sådanne udviklinger også kan ligge et forsøg på at bryde gennem deformationer til en mere oprindelig kristendomsforståelse.

En totalafvisning af neoprotestantiske ændringer og destruktioner ville kun være mulig, hvis man kunne rive to spørgsmål fra hinanden: 1. Hvad er sand kristendom? 2. Hvad er kristendommens sandhed? De to spørgsmål falder rigtig nok ikke sammen, og et svar på det ene er endnu ikke et svar på det andet (som ikke mindst Grundtvig har klargjort). Men det var fatalt, om de var hinanden helt uvedkommende. Ganske vist kommer man så ind i det dilemma, der ofte har plaget protestantisk teologi, nemlig enten under påberåbelse af en forpligtende sandhed at tillade sig at ændre eller remplacere de kristne tekster, eller også i viljen til at fastholde den uforfalskede kristendom til at relativere de sandheder, man har indset. De store nyprotestantiske teologier, ikke mindst Schleiermacher, er forsøg på at overvinde dette dilemma.

\section{Det reformatoriske mellem to deformationer}

Et mere sammensat forhold mellem reformation og deformation viser sig også i dialektisk teologis syn på sagen, der er blevet skelsættende for det 20. århundredes teologi. Med yderste skarphed forkastede man den liberale tradition som en forfalskning af den kristne forkyndelse. Men de dialektiske teologer tilsluttede sig ikke den konservative eller fundamentalistiske fløj, ej heller fulgte de katolicerende tendenser. De forkastede alle forsøg på at identificere åbenbaringens autoritet med bestemte opfattelsers gyldighed, og på at fiksere en ikke-deformeret grundbestand af det kristelige. Sådanne forsøg var i deres øjne lige så ulydige mod den talende Gud som de liberales humane gengivelse af budskabet. 
I Karl Barths dogmatik ${ }^{2}$ fører dette til en karakteristisk bestemmelse af det reformatoriske. Den reformatoriske afgørelse falder i lydighed mod åbenbaringens ord, der bringer alle andre ord til tavshed. Derved er der udtalt et nej til to sider. Den kirkelige forkyndelse står mod en dobbelt hæretisk afvigelse.

Afvisningen gælder på den ene side modernitetens ånd især i skikkelse af neo-protestantismen; dens påberåbelse af frihed og sandhed og historie viderefører ikke reformationen, men er dens forfalskning. Denne forfalskende modernisme finder Barth imidlertid ikke blot i teologiske nybrud i forlængelse af Oplysningen og idealisme, men også hos disse udviklingers modstandere, der søgte den ægte kristendom imod moderne deformationer, nemlig de pietistiske og konservative hævdelser af det gamle. De to dødsfjender er i Barths øjne to alen ud af et stykke, fordi de begge er udtryk for det moderne menneskes selvtægt over for Gud, hvor menneskets egen religiøsitet træder i stedet for Guds ord. Barth kalder denne hæresi for den "pietistisk-rationalistiske modernisme" (Kirchliche Dogmatik, I/1,33). Det er denne frontstilling, som en beskrivelse af Barth som "neo-ortodoks" ikke kan indfange.

Afvisningen gælder på den anden side den romerske katolicisme "i den skikkelse, som den har givet sig i det 16. århundrede i kampen mod reformationen" (sst.). Også hér underkastes ordets suverænitet under menneskelige forehavender. Netop katolicismens mest imponerende udfoldelser anser Barth for at være en deformerende varetagelse af den kristne forkyndelse.

Med denne dobbelte frontstilling ønsker Barth at tage højde for to magtfulde fakta, dels at reformationens virkningshistorie såvel som dens katolske modspil var præget af deformationer, dels at en reformatorisk besindelse er stedse nødvendig for at imødegå den altid aktuelle selvødelæggelse af den faktiske kristendom. Anderledes end al anden kritik af kristendommens deformation søger Barth ikke en ikke-deformeret normaltilstand; han er på det rene med, at vi altid befinder os i deformationers magnetfelt og må satse på det uforudsete alternativ.

Man skal imidlertid være klar over, at Barths tese balancerer på en knivsæg. Den ville vælte, hvis åbenbaringens ord faldt sammen med fikserbare sætninger og opfattelser, for ordet er aldrig noget givet, men skal høres som "ordet i ordene". Deri ligger dels en vidtgående mulighed for at spørge bag om alle de formationer og historiske kon-

2. Karl Barth, Kirchliche Dogmatik bd. I/1 (1932) og bd. I/2 (1938). Se hertil Barths foredrag fra kirkekampens begyndelse 1933: "Reformation als Entscheidung" i Karl Barth, Der Götze wackelt: Zeitkritische Aufsätze, Reden und Briefe von 1930 bis 1960, ed. Karl Kupisch (Berlin: Käthe Vogt Verlag 1961). 
tekster, ordet er givet i, og dels en pligt til omfattende at kritisere det bestående for at kunne høre på ny. Barths tese ville imidlertid også bryde sammen, hvis det var muligt at konstatere lydigheden mod ordet. Den findes kun som uforudset begivenhed. Ordet taler til dem, der altid allerede er i færd med at okkupere eller fordreje det. Reformation findes ikke som tilstand eller konstaterbar proces, men kun som overvindelse og imødegåelse af deformation; om man vil: som deformationens deformation.

Man skal gøre sig klart, at Barth - ham der med uovertruffen hårdhed har kritiseret nyprotestantismen - kommer tæt på den tredje og mest radikale måde at gøre det reformatoriske gældende på imod deformation (se ovenfor pkt. 3), den måde som har været på spil i de mest problematiske udfoldelser af nyprotestantismen. Han tager ikke blot afstand fra middelalderlige særudviklinger, ej heller blot fra den katolske kirkes formation i senantikken, men fra alle udfoldelser af en selvhævdende omgang med forkyndelsen. Det er i denne sammenhæng han gengiver det kirkelige dogme, og herudfra læser og udlægger han de bibelske tekster. Barths afvisning af nyprotestantismen har selv - det må hævdes på trods af Barths højlydte protester - nyprotestantisk præg.

\section{Hvad nu?}

Barths tese er derved ikke dementeret; den har blivende betydning, når man forsøger at bestemme det sammensatte forhold mellem reformation og deformation, og derved også prøver at finde en ny forholdsbestemmelse af ortodoksi og hæresi. Ellers falder man tilbage i den endeløse og ufrugtbare strid mellem de liberale (som ikke er nøjeregnende med den sande kristendom) og de konservative (som ikke for alvor indlader sig på sandhedsspørgsmålet), og en teologisk anstrengelse inspireret af reformationen ville være omsonst. Man må heller ikke falde tilbage bag om Barths forudsætning, nemlig at kristendommens deformation aldrig er tilfældig, men hænger sammen med dens indfældethed i den menneskelige historie. Derfor repræsenterer det reformatoriske en blivende udfordring der ikke falder sammen med reformationstidens skikkelser og begivenheder.

Barths tese har imidlertid også oplagte svagheder; at korrigere dem fører til en mere differentieret vurdering af nyprotestantismen. På tre punkter i hvert fald trænger Barths tese til en nyprotestantisk accentuering.

Kontroversen med en anden dialektisk teolog, nemlig Bultmann, afslører, at man ikke kan gøre sig færdig med den nyprotestantiske 
arv, på trods af faren for kristendommens alterering. Bultmann gør gældende imod Barth, at den historiske kritik er nødvendig netop med henblik på forståelsen af de bibelske tekster. Endvidere har Bultmann ret $\mathrm{i}$, at modstillingen mellem ordets tiltale, vi ikke kan disponere over, og de for os tilgængelige almene sandheder skal forankres i en universel refleksion vedrørende menneskelig eksistens, og en sådan refleksion kan ikke afvises som et forsøg på at gøre sig til herre over ordet.

Hos Barth er reformationens bestemmelse tæt knyttet til hans kamp imod naturlig og fornuftig teologi, til den udrensning af hedenske elementer, der ifølge hans udredninger ikke blev fuldbyrdet med fornøden klarhed i antik og reformatorisk teologi. Det er dog påfaldende, at fornuften og naturen optræder to steder i dette opgør. Snart er fornuften og "det naturlige menneske" hovedaktøren i menneskets oprør mod Gud og krumtappen i al selvopfunden gudserkendelse; men snart efter er fornuften den Logos, der identificeres med Kristus, og naturen er det Gud er og skaber. Begge dele ville man kun kunne hævde, hvis der var to slags Logos og to sæt natur, der intet havde med hinanden at gøre - og det kan da ikke være tilfældet, med mindre Logos og natur, både den guddommelige og den menneskelige, bliver intetsigende.

Barths polemik mod nyprotestantismen er overtilspidset. Han ser ikke tilstrækkeligt - dog er der åbninger i hans sidste år, hvor der hos hans liberale antipoder navnlig hos Schleiermacher og Ritschl foreligger fremstød i retning af at skelne mellem spørgsmålene om kristendommens sandhed og om den sande kristendom for derigennem at søge en konvergens af spørgsmålene. Også den behandling, Barth giver den romerske katolicisme, indeholder forenklinger; i II. Vaticanums tid har Barth endnu kunnet opleve og prise, at katolsk teologi kan sørge for overraskelser.

En sådan korrektion af Barths tese er ikke alene nødvendig for at opnå et differentieret billede af protestantisk teologihistorie, men også for at tilskynde til en videreudvikling af en reformatorisk inspireret teologi, der kan modstå vor tids fristelser til at forflygtige det teologiske tema. 